\title{
Induction of c-myc transcription by the v-Abl tyrosine kinase requires Ras, Raf1, and cyclin-dependent kinases
}

\author{
Xiaoming Zou, Sergei Rudchenko, Kwok-kin Wong, and Kathryn Calame ${ }^{1}$ \\ Departments of Biochemistry and Molecular Biophysics and Microbiology, Columbia University College of Physicians and \\ Surgeons, New York, New York 10032 USA
}

\begin{abstract}
$\mathbf{v}-\mathrm{Abl}$ is an oncogenic form of the c-Abl nonreceptor tyrosine kinase. $\mathrm{v}-\mathrm{Abl}$ induces transcription of c-myc, and c-Myc function is a necessary but not sufficient component of the $\mathrm{v}-\mathrm{Abl}$ transformation program. Previously we showed that the E2F site in the c-myc promoter is a v-Abl response element and that v-Abl appears to induce c-myc by initiating a phosphorylation cascade that ultimately activates E2F-binding proteins. In this work we have investigated the signaling pathway between the $\mathrm{V}$-Abl tyrosine kinase and activated E2F proteins. We show that the Ras GTPase and Raf1 serine/threonine kinase are required in this pathway. However, in contrast to other aspects of $\mathrm{v}$-Abl signaling, induction of c-myc transcription is independent of the Rac GTPase. Our results also establish a requirement for activated cyclin-dependent kinases (cdks), as $\mathrm{v}$-Abl-dependent induction of c-myc transcription is blocked by cdk inhibitor $\mathbf{p} 21$ and induction of $c-m y c$ is accompanied by activation of cdk2 and cdk4. Finally, we show that v-Abl-dependent induction of c-myc is accompanied by hyperphosphorylation of $\mathrm{pRb}, \mathrm{p} 107$, and $\mathrm{p} 130$. On the basis of these data, we propose a model for the signaling path from $\mathrm{v}$-Abl to c-myc.
\end{abstract}

[Key Words: v-Abl; c-myc; Ras/Raf; Rac; cdk; signal transduction]

Received October 17, 1996; revised version accepted January 21, 1997.

Abelson murine leukemia virus (A-MuLV) encodes an oncogenic form of the Abelson kinase, $\mathrm{v}-\mathrm{Abl}$ (Risser and Green 1988). v-Abl is a fusion protein in which portions of the retroviral Gag protein replace the amino-terminal $\mathrm{SH} 3$ domain of $\mathrm{c}-\mathrm{Abl}$, rendering the tyrosine kinase activity constitutive. Until recently, little was known about functionally important substrates of the Abelson kinases or about possible signal transduction paths which their action might initiate. Development of temperature-sensitive forms of $\mathrm{v}$-Abl led to the identification of the c-myc gene as an important target of $\mathrm{v}$-Abl activity. In fibroblasts, myeloid cells, and pre-B cells, v$\mathrm{Abl}$ induces transcription of $\mathrm{c}-m y c$ which is independent of new protein synthesis, suggesting that $\mathrm{v}$-Abl acts by post-translational modification of existing c-myc regulatory proteins (Cleveland et al. 1989; Chen and Rosenberg 1992; Renshaw et al. 1992). Subsequently, dominantnegative forms of $\mathrm{c}-\mathrm{Myc}$ were used to show that $\mathrm{c}-\mathrm{Myc}$ was required for transformation by either $v-a b l$ or $b c r /$ $a b l$, establishing the importance of the c-myc gene as an ultimate target for the activity of $\mathrm{v}-\mathrm{Abl}$ and $\mathrm{BCR} / \mathrm{ABL}$ (Sawyers et al. 1992).

We have been studying $\mathrm{v}$-Abl-dependent induction of $c-m y c$ transcription as a way of gaining further under-

${ }^{1}$ Corresponding author.

E-MAIL klc1@columbia.edu; FAX (212) 305-1468. standing of this critical aspect of $\mathrm{v}-\mathrm{Abl}$ signaling. Our previous work showed that $\mathrm{v}$-Abl can induce c-myc transcription through the E2F site located upstream of the P2 transcription initiation site in the c-myc promoter. We showed further that E2F sites alone are sufficient to confer $\mathrm{v}$-Abl reponsiveness on a heterologous promoter (Wong et al. 1995). This induction requires the SHI (kinase) and SH2 domains of $\mathrm{v}$-Abl but does not require the carboxy-terminal nuclear localization signal, SH3 binding, DNA-binding, or actin-binding domains (Wong et al. 1995|. Thus, $\mathrm{v}-\mathrm{Abl}$ appears to induce c-myc transcription by initiating a phosphorylation cascade that ultimately increases the transcriptional activating ability of E2F site binding proteins. Because we knew that the initial signal for c-myc transcriptional induction came from $\mathrm{v}$ $\mathrm{Abl}$ tyrosine kinase and the penultimate event was activation of E2F-dependent transcription, we wanted to determine the intermediate biochemical steps in this signal transduction pathway.

In this study we have determined the components of the signaling pathway that links $\mathrm{v}-\mathrm{Abl}$ and induction of c-myc transcription. The roles of the Ras GTPase, Raf1 serine/threonine kinase, and Rac GTPase were assessed by cotransfecting a series of dominant-negative and constitutively active mutants. $\mathrm{v}-\mathrm{Abl}$ induces c-myc transcription via a pathway that requires Ras and Raf 1 , but not Rac. Furthermore, we show that overexpression of 
p21, an inhibitor of cyclin-dependent kinases (cdks), blocks v-Abl-dependent induction of c-myc transcription. Consistent with this finding, $\mathrm{v}$-Abl causes activation of cdk2 and cdk 4 and hyperphosphorylation of the retinoblastoma $(\mathrm{Rb})$ protein, $\mathrm{p} 107$, and $\mathrm{p} 130$. We propose that $\mathrm{v}$-Abl-dependent activation of Raf1 is linked to activation of $\operatorname{cdk} 2 / \mathrm{cdk} 4$ through the recently identified cdc25 pathway. Thus, these studies have resulted in the identification of the major components of a signaling pathway between $\mathrm{v}-\mathrm{Abl}$ and one of its functionally important target genes, c-myc.

\section{Results}

Ras GTPase and Raf1 Ser/Thr kinase are required for the induction of $c$-myc transcription by $\mathrm{v}-\mathrm{Abl}$

Our previous work suggested that induction of c-myc transcription by v-Abl depended on initiation of a phosphorylation cascade (Wong et al. 1995). We wondered if this pathway involved activation of Ras which, like induction of c-myc (Sawyers et al. 1992), is required for Abl-dependent transformation (Goga et al. 1995; Sawyers et al. 1995). To test this hypothesis, we utilized our previously developed cotransfection assay (Wong et al. 1995). A v-Abl expression plasmid (pAB160-19) and a lu- ciferase reporter (Luc) dependent on the murine c-myc promoter (extending from nucleotide -140 to nucleotide +340 ) were cotransfected into 4A2 fibroblasts (Renshaw et al. 1992) with or without a plasmid encoding a dominant-interfering mutant of Ras, Ras N17 (Stacey et al. 1991). v-Abl activated the c-myc promoter reporter approximately six- to sevenfold compared to the appropriate control lacking v-abl cDNA (Fig. 1A, lanes 1,2). However, in the presence of dominant-negative Ras N17, vAbl-dependent activation was ablated completely (Fig. $1 \mathrm{~A}$, lanes 3,4$)$. We then tested the effect of cotransfecting a plasmid encoding a constitutively active Ras mutant, Ras V12 (Conrad and Gutierrez-Hartmann 1992). Ras $\mathrm{V} 12$ activated c-myc transcription, and $\mathrm{v}-\mathrm{Abl}$ was unable to activate it further in the presence of Ras V12 (Fig. 1A, lanes 5,6$)$. These results show that Ras GTPase activity is required downstream of $\mathrm{v}-\mathrm{Abl}$ for $\mathrm{v}$ - $\mathrm{Abl}$ to activate c-myc transcription.

The Ser/Thr kinase Raf1 is an immediate downstream effector for many Ras-dependent events (Marshall 1995). Therefore, we used the same approach to ask whether Raf1 was also required for $\mathrm{v}$-Abl-dependent activation of c-myc transcription. Expression of RafC4, a dominantnegative form of Raf1 (Bruder et al. 1992), efficiently inhibited activation of the c-myc promoter by v-Abl (Fig. 1B lanes 3,4$)$. In addition, a constitutively active mutant
A $\quad-1+v-A b l$

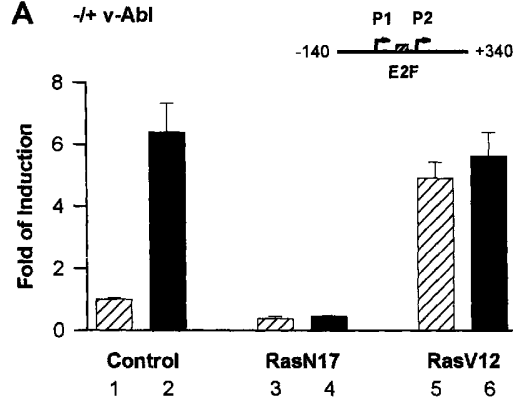

C $\quad-l+v-A b l$

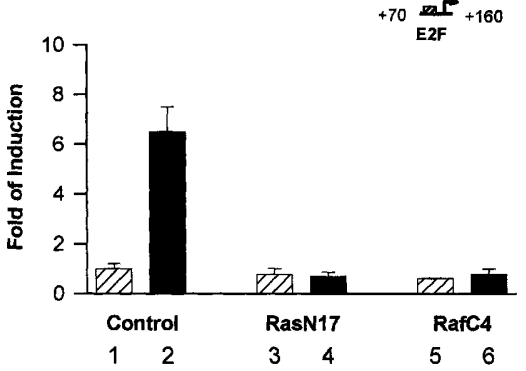

B $\quad+$ + v-Abl

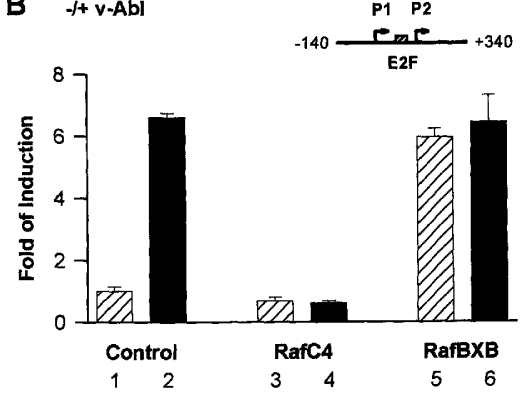

D $\quad+$ p 65
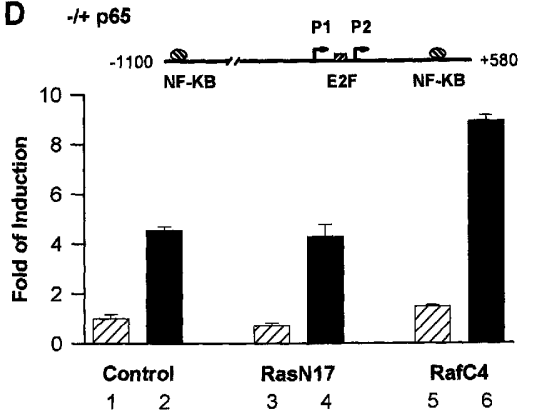

Figure 1. Ras and Raf are required for trans-activation of c-myc by v-Abl. (A) 4A2 cells were transfected with $5 \mu \mathrm{g}$ of a luciferase reporter dependent on regions of the murine c-myc promoter from -140 to +340 $\mathrm{bp}$ and expression plasmids for $\mathrm{v}-\mathrm{Abl}$ and dominant-negative (N17) or constitutive active (V12) Ras. The hatched bars were transfected with $5 \mu \mathrm{g}$ of pLTR, the promoter control plasmid. The solid bars were transfected with $5 \mu \mathrm{g}$ of pAB160-19wt, expression plasmid encoding wild-type v-Abl. (Lanes 1,2) Control plasmid; (lanes 3,4) $0.5 \mu \mathrm{g}$ of Ras N17, expression plasmid of dominant-negative Ras; (lanes 5,6) $5 \mu \mathrm{g}$ of Ras V12, expression plasmid of constitutive active Ras. The average luciferase activity of unstimulated cells transfected with vector plasmid was set as 1 . The fold induction shown is the mean and standard deviation determined from three independent transfections of one representative experiment. (B) $4 \mathrm{~A} 2$ cells were transfected with dominant-negative or constitutively active Rafl expression constructs and the same reporter and v-Abl expression plasmids as in $A$. (Lanes 1,2) Vector for Rafl mutants; (lanes 3,4) $5 \mu$ of RafC4, expression plasmid of dominant-negative Raf1; (lanes 5,6) $5 \mu \mathrm{g}$ of RafBXB, expression plasmid of constitutive active Rafl. (C) 4A2 cells were transfected with $5 \mu \mathrm{g}$ of a reporter dependent on +70 to $+160 \mathrm{bp}$ of the murine c-myc promoter and the combination of $\mathrm{v}$-Abl and dominantnegative Ras or Raf expression plasmids. (Lanes 1,2) Vector control; (lanes 3,4) $0.5 \mu$ g of Ras N17; (lanes 5,6) $5 \mu \mathrm{g}$ of RafC4. (D) 4A2 cells were transfected with $5 \mu \mathrm{g}$ of a luciferase reporter dependent on regions of the murine c-myc promoter from -1100 to $+580 \mathrm{bp}$ and the combination of p 65 and dominant-negative Ras or Raf. The hatched bars were transfected with $5 \mu \mathrm{g}$ of pCMV, the control expression vector (cytomegalovirus). The solid bars were transfected with $5 \mu \mathrm{g}$ of CMVp65, expression plasmid encoding the large subunit of NF-kB. (Lanes 1,2) Vector; (lanes 3,4) $0.5 \mu \mathrm{g}$ of Ras N17; (lanes 5,6) RafC4. In each panel, a diagram of the reporter, not drawn to scale, is shown. 
of Rafl, RafBXB (Bruder et al. 1992) activates the c-myc promoter alone and there is no further activation with $\mathrm{v}$-Abl (Fig. 1B, lanes 5,6). We also found that dominantnegative forms of Ras and Rafl blocked $v$-Abl-dependent activation of a truncated $\mathrm{c}-\mathrm{myc}$ promoter reporter construct, $+70 /+160 \mathrm{Luc}$ (Fig. 1C), and a minimal TATA box dependent on four E2F-binding sites (data not shown). In these templates the response to $\mathrm{v}$-Abl depends solely on the E2F sites (Wong et al. 1995).

We wished to be sure that expression of dominantnegative forms of Ras and Raf 1 did not inhibit activation of $c-m y c$ transcription nonspecifically. Therefore, we tested the ability of the p 65 subuint of NF- $\kappa$ B to activate the c-myc promoter in the absence or presence of dominant-negative Ras or Rafl, as NF- $\mathrm{kB}$ activation does not involve Ras or Raf and we have shown previously that NF- $\mathrm{B}$ sites are not involved in activation of c-myc by $\mathrm{v}$-Abl (Wong et al. 1995). We cotransfected a p65 expression plasmid with $-1100 /+580$ Luc, a larger c-myc promoter reporter construct which contains the two NF-кB responsive sites (Duyao et al. $1990 \mathrm{a}, \mathrm{b}$ ), into 4A2 cells. p65 activated this reporter approximately fivefold (Fig. $1 D$, lanes 1,2$)$. In the presence of dominant-negative Ras N17 (Fig. 1D, lanes 3,4) or dominant-negative RafC4 (Fig. ID, lanes 5,6), p65 still fully activated c-myc transcription. Thus, we conclude that inhibition of $\mathrm{v}$-Abl-dependent activation of $\mathrm{c}-\mathrm{myc}$ transcription by Ras $\mathrm{N} 17$ and RafC4 is specific. Taken together, these data demonstrate that activation of Ras and Rafl Ser/Thr kinase is required as a downstream effector for v-Abl-dependent trans-activation of $\mathrm{c}-\mathrm{myc}$ transcription.

\section{Activity of the Rac GTPase is not required for $\mathrm{v}-\mathrm{Abl}$ to activate $c$-myc transcription}

The v-Abl tyrosine kinase apparently uses more than one independent signaling pathway to transform cells. It has been shown that Rac and Ras are both important for $\mathrm{v}$-Abl to activate mitogenesis, and a dominant-negative Rac mutant can inhibit $\mathrm{v}$-Abl-induced activation of the TPA response element (TRE) and the serum response element (SRE) (Renshaw et al. 1996). Therefore, we tested whether Rac activity is required for $\mathrm{v}-\mathrm{Abl}$ to activate c-myc transcription. In the cotransfection assay shown in Figure 2, v-Abl activated the c-myc promoter reporter approximately sixfold (Fig. 2A, lanes 1,2); how- ever, in contrast to the results using dominant-negative forms of Ras and Raf, this activation was fully retained in the presence of an expression plasmid encoding dominant-negative Rac, V12N17rac1 (Ridley et al. 1992) (Fig. $2 \mathrm{~A}$, lanes 3,4$)$. The activity of cotransfected V12N17rac1 in our system was confirmed by its ability to inhibit $\mathrm{v}$-Abl-dependent activation of an SRE-dependent promoter (Fig. 2B, cf. lanes 3 and 4 with lanes 1 and 2) as reported previously (Renshaw et al. 1996). Thus, we conclude that Rac activity is not required for $\mathrm{v}-\mathrm{Abl}$ to transactivate $c-m y c$ transcription in our system.

\section{$V$-Abl activates cdks}

Because $\mathrm{v}$-Abl activation of $\mathrm{c}-\mathrm{myc}$ transcription requires the E2F site, we assume that E2F site binding proteins are activated in response to $\mathrm{v}$-Abl. The activity of $\mathrm{E} 2 \mathrm{~F}-$ DP heterodimers is modulated by association with $R b$ family proteins and the ability of $\mathrm{Rb}$ family proteins to associate is regulated by phosphorylation (Adams and Kaelin 1995; Chen et al. 1995; Weinberg 1995; Cobrinik 1996). Rb family proteins are phosphorylated by cdks: cdk4-cyclin D is active early in G1, and cdk2-cyclinE is active later in $G_{1}$ (Weinberg 1995). Therefore, we asked whether cdk activity changed in response to $\mathrm{V}$-Abl signaling.

We took advantage of the D5 cell line, a 3 T3 subclone transformed with a temperature-sensitive form of $\mathrm{v}$-Abl (Renshaw et al. 1992). At the permissive temperature $\left(32^{\circ} \mathrm{C}\right), \mathrm{D} 5$ cells are transformed, displaying serum- and anchorage-independent growth and increased transcription of their endogenous $\mathrm{c}-m y c$ gene. At the nonpermissive temperature $\left(39^{\circ} \mathrm{C}\right)$, the cells revert to serum- and anchorage-dependent growth typical of 3T3 cells. D5 cells were made quiescent by serum starvation at $39^{\circ} \mathrm{C}$ for $48 \mathrm{hr}$. Subsequently the temperature was shifted to $32^{\circ} \mathrm{C}$ to activate $\mathrm{v}$ - $\mathrm{Abl}$; under these conditions, growth is dependent solely on $\mathrm{v}-\mathrm{Abl}$, as the cells are still serum starved. We also compared cells growing in serum at the permissive and nonpermissive temperatures; at the permissive temperature these cells are receiving signals from both $\mathrm{v}-\mathrm{Abl}$ and serum. Immunoprecipitated $\mathrm{v}-\mathrm{Abl}$ was immunoblotted with antibody to phosphotyrosine to confirm that $\mathrm{v}$-Abl kinase was temperature sensitive in our system (Fig. 3A, panel a).
Figure 2. Rac is not required for trans-activation of c-myc by v-Abl. (A) $4 \mathrm{~A} 2$ cells were transfected with $5 \mu \mathrm{g}$ of a luciferase reporter dependent on regions of the murine c-myc promoter from -140 to $+340 \mathrm{bp}$ and the combination of $\mathrm{v}-\mathrm{Abl}$ and dominant-negative Rac expression constructs. (Lanes 1,2) Control plasmid; (lanes 3,4) $5 \mu \mathrm{g}$ of V12N17rac1, expression plasmid for dominant-negative Rac. (B) 4A2 cells were transfected as in $A$, except with $5 \mu \mathrm{g}$ of SRE-Fluc, a luciferase reporter dependent on c-fos SRE.
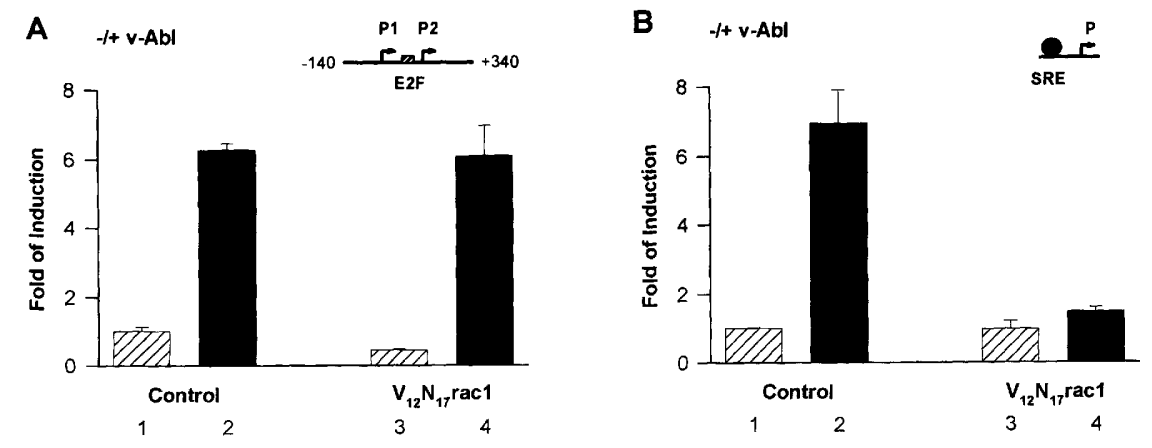
A
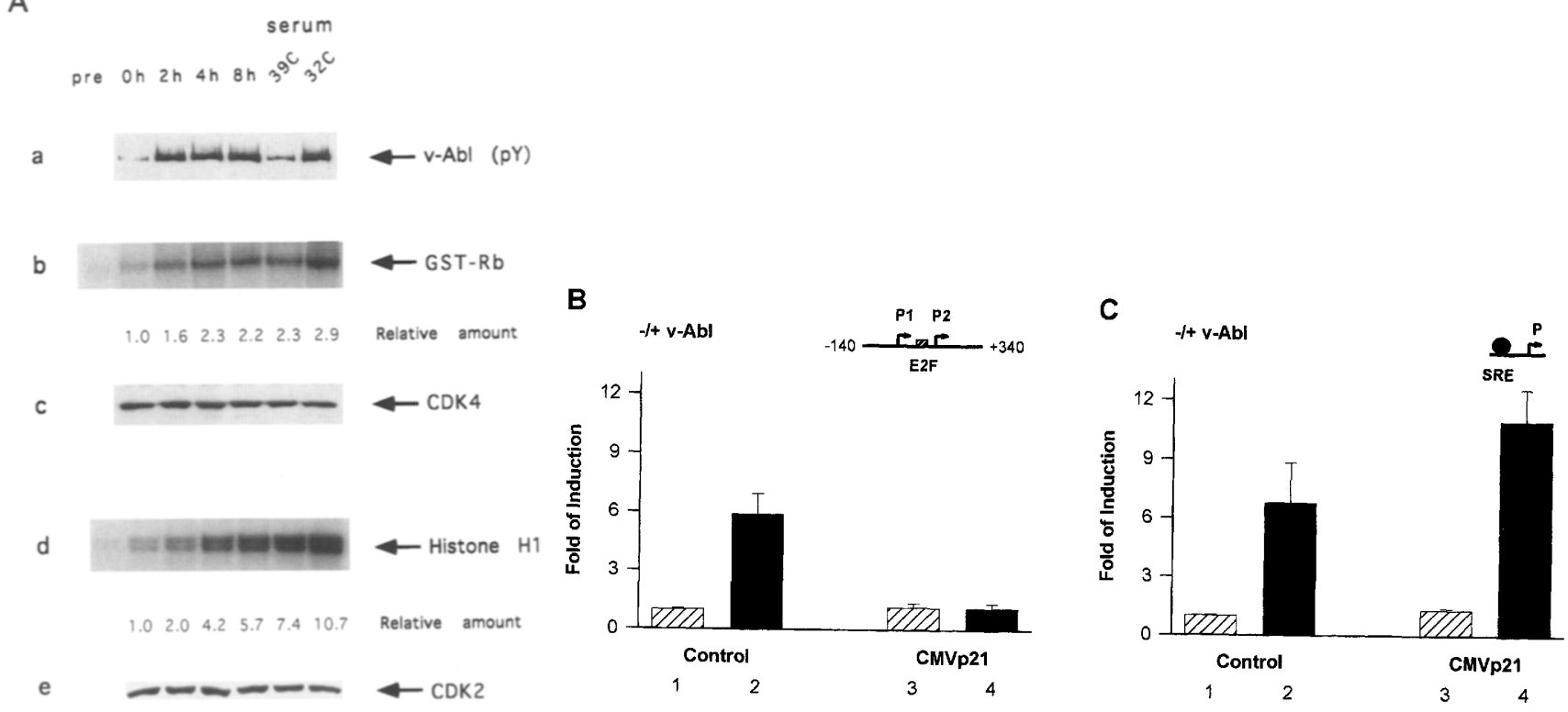

Figure 3. $\mathrm{v}$-Abl activates $\mathrm{cdk} 2 / \mathrm{cdk} 4$ and $\mathrm{cdk}$ activity is necessary for $\mathrm{v}$-Abl-dependent trans-activation of c-myc transcription. $(A, a)$ v-Abl autophosphorylation in D5 cells. D5 cells were made quiesent by senum starvation at $39^{\circ} \mathrm{C}$ for $48 \mathrm{hr}$, shifted to $32^{\circ} \mathrm{C}$ and harvested $0,2,4$, and $8 \mathrm{hr}$ after temperature shift. D5 cells exponentially growing at both $39^{\circ} \mathrm{C}$ and $32^{\circ} \mathrm{C}$ with $10 \%$ serum were also analyzed. Lysates (50 $\mathrm{ug}$ of protein) were immunoprecipitated with $\mathrm{v}$-Abl antiserum, run on a $6 \%$ gel, and probed with phosphotyrosine antibody. (b) Cyclin D1-associated kinase activity in D5 cells. The same D5 cell lysates (200 $\mu \mathrm{g}$ of protein) as in $a$ were immunoprecipitated with an anti-cyclin D1 antibody or preimmune serum. Immune complexes were assayed for kinase activity using GST-Rb as substrates. ${ }^{32} \mathrm{P}$-Labeled GST-Rb was shown. The relative amounts are given below the lanes. (c) The same protein lysates $(25 \mu \mathrm{g}$ of protein) were immunblotted with anti-cdk4 antibody. (d) cdk2 kinase activity in D5 cells. D5 cells lysates were made the same way as above. Lysates (50 $\mu \mathrm{g}$ of protein) were immunoprecipitated with an anti-cdk2 antibody or preimmune serum. Immune complexes were assayed for kinase activity using histone $\mathrm{Hl}$ as substrates. ${ }^{32} \mathrm{P}$-Labeled histone $\mathrm{H} 1$ was shown. The bands were quantitated and the amounts relative to $0 \mathrm{hr}$ are shown below the lanes. (e) The same protein lysates $(25 \mu \mathrm{g}$ of protein) as in $d$ were immunblotted with anti-cdk2 antibody. (B) 4A2 cells were transfected with $5 \mu \mathrm{g}$ of a luciferase reporter dependent on regions of the murine c-myc promoter from -140 to $+340 \mathrm{bp}$ and the combination of expression plasmids for v-Abl and p21. (Lanes 1,2) Control plasmid; (lanes 3,4) $5 \mu \mathrm{g}$ of CMVp21. (C) 4A2 cells were transfected with $5 \mu \mathrm{g}$ of the SRE-Fluc, a luciferase reporter dependent on c-fos SRE and the combination of expression plasmids for $\mathrm{v}$-Abl and $\mathrm{p} 21$. (Lanes 1,2) Control plasmid; (lanes 3,4) $5 \mu \mathrm{g}$ of CMVp21.

D-type cyclin-associated kinase activity was assayed in vitro by immunoprecipitating with cyclin D1 antibodies at various time following temperature shift, and the associated kinase activity was assayed by using glutathione $S$-transferase (GST)-Rb protein substrates. This activity primarily belongs to $\operatorname{cdk} 4$, as $\operatorname{cdk} 4$ is the major partner of D-type cyclin complexes in fibroblasts (Matsushime et al. 1994). A small but reproducible increase (twofold) in kinase activity was observed following activation of $\mathrm{v}$-Abl in the absence of serum (Fig. 3A, panel b). D-type cyclin activity was increased at both temperatures in the presence of serum, although it was slightly higher at the permissive temperature. In all cases, the amount of cdk4 protein, determined by immunoblot (Fig. 3A, panel c), did not change significantly.

$\mathrm{Cdk} 2$ activity was similarly assayed in vitro using histone $\mathrm{H} 1$ as substrate. An increase in cdk2 activity was observed at $2 \mathrm{hr}$ and reached 5.7 -fold by $8 \mathrm{hr}$ (Fig. 3A, panel d). Cdk2 activity was elevated at both temperatures in the presence of serum, although activity was slightly higher in the presence of $\mathrm{v}$-Abl. The amount of cdk2 protein, determined by immunoblot (Fig. 3A, panel e), did not change significantly in any sample. Thus, we observe a $\mathrm{v}$-Abl-dependent increase in cdk activity, especially for cdk2, which is consistent with the possiblity of $\mathrm{v}$-Abl-dependent phosphorylation of $\mathrm{Rb}$ family proteins and subsequent activation of E2F proteins.

Cdk activity is required for $v$-Abl-dependent induction of $c$-myc transcription

To test directly whether cdk activity is required for vAbl-dependent induction of c-myc transcription, we expressed $\mathrm{p} 21$ in the cotransfection assay along with $\mathrm{v}$-Abl and the reporter dependent on the c-myc promoter. p21 is a universal inhibitor of cdk activity (Xiong et al. 1993). $\mathrm{v}$-Abl activated the $-140 /+340 \mathrm{Luc} c-m y c$ promoter reporter approximately sixfold (Fig. 3B, lane 1,2); however, in the presence of $\mathrm{p} 21$, this activation was ablated completely (Fig. 3B, lane 3,4). As a control, we examined the effect of $\mathrm{p} 21$ on $\mathrm{v}$-Abl-dependent activation of a reporter dependent on an SRE. Because $\mathrm{v}$-Abl-dependent activation of a SRE requires Rac (Fig. 2; Renshaw et al. 1996), it appears to proceed by a different signal transduction 
path. v-Abl activated SRE-Fluc (a luciferase reporter dependent on c-fos SRE) more than sixfold (Fig. 3C, lanes 1,2 ), and this activation was not affected by cotransfection of the p21 expression plasmid (Fig 3C, lanes 3,4). Thus, inhibition of $\mathrm{v}$-Abl-dependent induction by $\mathrm{p} 21$ expression is specific for c-myc transcription and is not required for SRE-dependent transcription. We conclude that cdk activity is required for trans-activation of c-myc transcription by $\mathrm{v}-\mathrm{Abl}$.

\section{$R b$ family proteins are hyperphosphorylated in response to $\mathrm{V}$ - $A$ bl signaling}

Because $\mathrm{Rb}$ family proteins are primary substrates of the cdks, as well as regulators of E2F proteins, we examined the phosphorylation states of pRb, p107, and p130 in D5 cells. Hypophosphorylated forms of $\mathrm{pRb}, \mathrm{p} 107$, or $\mathrm{p} 130$ migrate faster in SDS-polyacrylamide gels than hyperphosphorylated forms and can be discerned using immunoblots. Cells were grown at both temperatures in the absence of serum as described above. Whole-cell extracts were prepared from these cells, and immunoblots were analyzed with antisera against c-Myc, pRb, p107, and p130. Activation of the $\mathrm{v}$-Abl tyrosine kinase (Fig. 4A, panel a) led to an increase in C-Myc (Fig. 4A, panel b), consistent with previous reports (Renshaw et al. 1992) and thereby demonstrating that $\mathrm{v}-\mathrm{Abl}$ was signaling correctly. Before temperature shift, approximately half of the $\mathrm{pRb}$ was in the high-mobility hypophosphorylated form; after temperature shift, nearly all was found in the low-mobility hyperphosphorylated form (Fig. 4A, panel c). Similarly, pl07 became increasingly hyperphosphorylated, as evidenced by lower mobility, following v-Abl activation by temperature shift (Fig. 4A, panel d). Of the three family members, the phosphorylation state of $\mathrm{p} 130$ changed most dramatically. At the nonpermissive tem- perature, p130 was in two higher mobility hypophosphorylated forms; $8 \mathrm{hr}$ after temperature shift, p130 was entirely in a lower mobility hyperphosphorylated form (Fig. 4A, panel e). In addition, less pl30 was observed $8 \mathrm{hr}$ after temperature shift, although we do not know whether the amount actually decreased or whether the hyperphosphorylated form reacts less well with antiserum. We conclude that $\mathrm{pRb}, \mathrm{p} 107$, and p130 are hyperphosphorylated in response to $\mathrm{v}-\mathrm{Abl}$ signaling and that the amount of p130 may decrease in response to v-Abl.

\section{Overexpression of $p R b$ blocks $v$-Abl-dependent induction of $c$-myc transcription}

Association of E2F-DP heterodimers with pRb, p107, and/or p130 inhibits their ability to act as transcriptional activators and can create transcriptional repressors (Cobrinik 1996). Thus, our results are consistent with a model in which $\mathrm{v}-\mathrm{Abl}$ signaling results in activation of cdks, phosphorylation of $\mathrm{Rb}$ family proteins, release of $\mathrm{Rb}$ proteins from association with E2F-DP and, finally, activation of $c-m y c$ transcription via the E2F site. To examine this model further, we used the cotransfection assay to test whether overexpression of $\mathrm{pRb}$ could block v-Abl-dependent trans-activation of c-myc transcription. Our results show that ectopic pRb does block c-myc transcription in this assay (Fig. 4B, cf. lanes 3 and 4 with lanes 1 and 2). As a control, we examined the effect of $\mathrm{pRb}$ on $\mathrm{v}$-Abl-dependent activation of a reporter dependent on a SRE; this activation was not affected by cotransfection of the $\mathrm{Rb}$ expression plasmid (Fig. 4C, cf. lanes 3 and 4 with lanes 1 and 2). These results are consistent with the idea that c-myc transcription is sensitive to the levels of hypophosphorylated $\mathrm{pRb}$ and lend support to the suggestion that $\mathrm{v}$-Abl activation via $\mathrm{E} 2 \mathrm{~F}$ sites depends on phosphorylation of $\mathrm{Rb}$ family proteins.

\section{A}
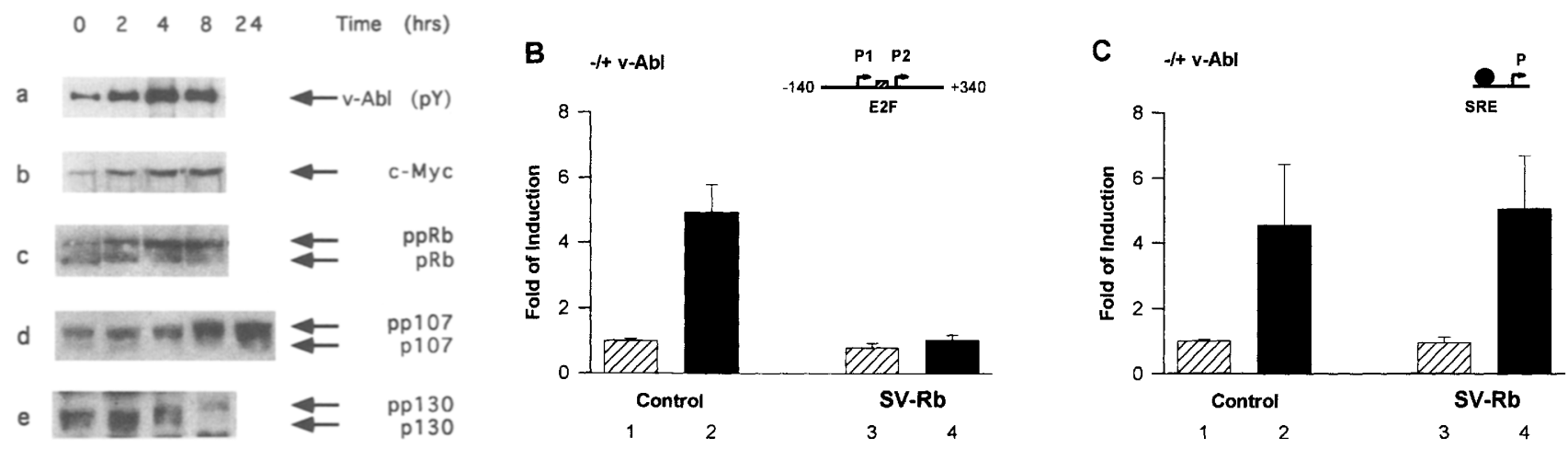

Figure 4. Rb family proteins are hyperphosphorylated following v-Abl activation, and overexpression of pRb blocks v-Abl-dependent trans-activation of c-myc transcription. (A) D5 cells were made quiesent by serum starvation at $39^{\circ} \mathrm{C}$ for $48 \mathrm{hr}$, and shifted to $32^{\circ} \mathrm{C}$. Whole-cell extracts were prepared from these cells at indicated time points and subjected to Western blot analysis using antibodies against c-Myc, pRb, p107, and p130. For $a$, the same D5 cell lysates $(50 \mu \mathrm{g})$ were immunoprecipitated with an antiserum against $\mathrm{v}$-Abl and probed with phosphotyrosine antibody. (B) 4A2 cells were transfected with $5 \mu \mathrm{g}$ of a luciferase reporter dependent on regions of the murine $\mathrm{c}$-myc promoter from -140 to $+340 \mathrm{bp}$ and the combination of $\mathrm{v}$ - $\mathrm{Abl}$ and $\mathrm{Rb}$ expression plasmids. (Lanes 1,2 ) Control plasmid; (lanes 3,4) $5 \mu \mathrm{g}$ of pSV-Rb, expression plasmid for Rb. (C) 4A2 cells were transfected with $5 \mu \mathrm{g}$ of SRE-Fluc and the combination of expression plasmid for $\mathrm{v}-\mathrm{Abl}$ and $\mathrm{Rb}$. (Lanes 1,2) Control plasmid; (lanes 3,4) $5 \mu \mathrm{g}$ of $\mathrm{pSV}-\mathrm{Rb}$. 


\section{Discussion}

$\mathrm{v}$-Abl induces c-myc transcription by initiating a phosphorylation cascade that ultimately activates E2F transcription factors (Wong et al. 1995). In this study we have identified key components of the signaling pathway between $\mathrm{v}$-Abl and activated E2F site binding proteins. We propose that $\mathrm{v}-\mathrm{Abl}$ induces $\mathrm{c}-\mathrm{myc}$ transcription by the pathway illustrated in Figure 5. This path is not the only signaling pathway that $\mathrm{v}$-Abl utilizes to carry out its full program of cell transformation and may not be the only path used to induce c-myc. However, this represents the most complete understanding to date of a signaling pathway from v-Abl to a functionally important target gene.

Ras and Raf1 are required for $v$-Abl-dependent induction of $c$-myc

A requirement for the Ras GTPase in v-Abl-dependent induction of $c-m y c$ is consistent with previous data showing that both Ras and c-Myc are required for $\mathrm{v}-\mathrm{Abl}$ and BCR/ABL-dependent transformation (Smith et al. 1986; Sawyers et al. 1992, 1995). Although v-Abl and $\mathrm{BCR} / \mathrm{ABL}$ activate $\mathrm{Ras}$ via adaptor proteins that associate with BCR sequences (Pendergast et al. 1993) or the proline-rich SH3-binding domain (SBD) in the carboxyl terminus (Feller et al. 1994; Nichols et al. 1994; Ren et al. 1994; Goga et al. 1995), we believe that association of

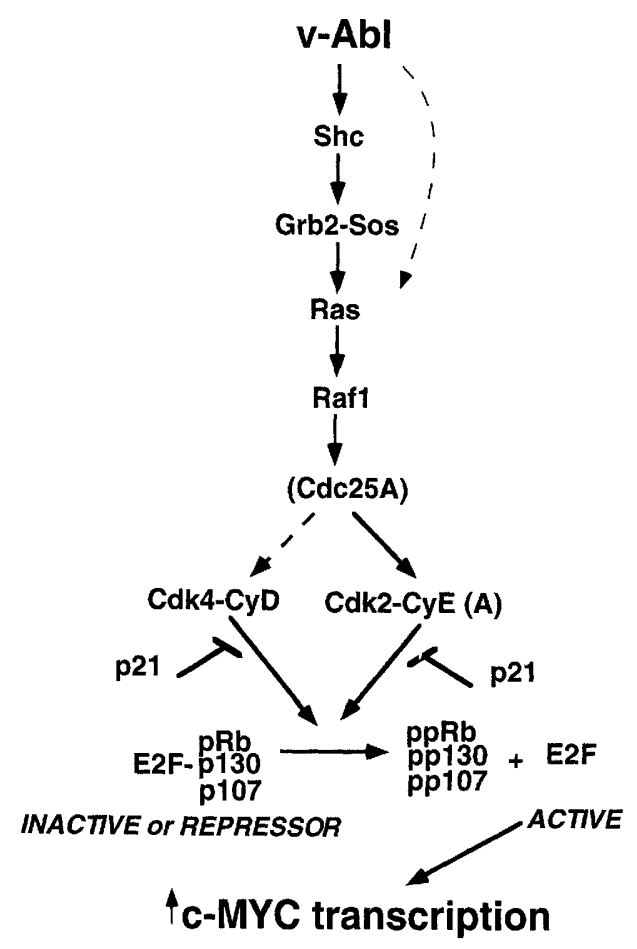

Figure 5. Model for signal transduction from v-Abl to activation of c-myc transcription. Steps that are consistent with current data, but not definitely established, are indicated by broken lines. Because the role of cdc $25 \mathrm{~A}$ is implied but not proven, it is shown in parenthesis.
$\mathrm{v}-\mathrm{Abl}$ with Shc, which requires the $\mathrm{v}-\mathrm{Abl} \mathrm{SH} 2$ domain (Raffel et al. 1996), is critical for activation of E2F proteins. The $\mathrm{SH} 2$ domain, but not the SBD of $\mathrm{v}-\mathrm{Abl}$, is required for $\mathrm{v}$-Abl-dependent trans-activation of $\mathrm{c}$-myc transcription (Wong et al. 1995), and c-Myc complements mutations in the $\mathrm{SH} 2$ domain of $\mathrm{BCR} / \mathrm{ABL}$ in a transformation assay (Afar et al. 1994). However, our data do not rule out the possibility (broken line in Fig. 5) that activation of Ras by an adaptor such as Crkl may be an alternate path by which $\mathrm{v}$ - $\mathrm{Abl}$ induces $\mathrm{c}$-myc transcription via Ras.

\section{E2F activation by $v-A b I$ does not require Rac}

While c-Myc is required for $\mathrm{v}$-Abl-dependent transformation, its induction is not sufficient for transformation (Sawyers et al. 1992). The Ras-related GTPase Rac has been shown to be necessary for activation of a mitogenic program by v-Abl (Renshaw et al. 1996). Rac is required for induction of TRE-dependent transcription by $\mathrm{v}$-Abl, whereas Rac, Ras, and Raf1 are required for $\mathrm{v}-\mathrm{Abl}$ to induce SRE-dependent transcription (Renshaw et al. 1996). We show that Ras and Rafl, but not Rac, are required for $\mathrm{v}$-Abl to induce the $\mathrm{c}-m y c$ promoter. This emphasizes that $\mathrm{v}$-Abl-dependent induction of promoters containing SREs and TREs (presumably corresponding to c-fos and c-jun, respectively in vivol proceeds by pathways distinct from that for $c-m y c$ and is consistent with the facts that neither the c-fos nor the c-jun promoter is regulated by E2F sites and that v-Abl increases expression of c-Myc but not Fos or JunB in a myeloid line /Cleveland et al. 1989).

Cdc25 may link $v$-Abl-dependent activation of Raf1 to activation of cdks

Our work and that of others suggests that mitogen-activated protein kinase (MAPK) may not be involved in E2F site-dependent activation by v-Abl via Rafl. Dominantnegative Rac inhibits $\mathrm{v}$-Abl-dependent activation of MAPK (Renshaw et al. 1996) but fails to block v-Abldependent induction of c-myc transcription (Fig. 2). In addition, a synthetic inhibitor of the MAPK pathway, PD 098059 (Dudley et al. 1995) failed to inhibit v-Abl transactivation of $c-m y c$ in our standard assay (data not shown|. Finally, in the murine mast cell line ICDP, v$\mathrm{Abl}$ induces Shc phosphorylation but not MAPK activation (Owen-Lynch et al. 1995).

We suggest, but have not yet demonstrated, that $\mathrm{v}-\mathrm{Abl}$ is linked to activation of E2F proteins via a second path from Raf1 that involves the cdc25A phosphatase. cdc25 activates cdc 2 and cdk 2 by dephosphorylating a critical tyrosine (Y15) in their nucleotide-binding domains (Jinno et al. 1994; Galaktionov et al. 1995). cdk4 and cdk 6 may also be activated by cdc 25 because this tyrosine in their nucleotide-binding domains is conserved (Terada et al. 1995).

$c d k s$ are required for $\mathrm{V}$-Abl-dependent induction of $c$-myc transcription

cdk inhibitor p21 specifically blocked the v-Abl-depen- 
dent induction of c-myc transcription but not induction of an SRE-dependent promoter (Fig. 3B,C), demonstrating that cdk activity is required for $\mathrm{v}$-Abl-dependent trans-activation of c-myc transcription. This is corroborated by increased activity of cdk2 and cdk 4 when D5 cells are signaled by v-Abl to proliferate (Fig. $3 \mathrm{~A}$ ). cdk2 can form complexes with both E2F-p107 and E2F-p130. These higher-order complexes may be intermediates whose subsequent disruption yields free, active E2F-DP heterodimers (Zhu et al. 1995; Shiyanov et al. 1996). This possibility is consistent with the fact that cdk2-containing E2F complexes are seen during $S$ phase in normal cells but are observed throughout the cell cycle in $\mathrm{v}$-Abltransformed D5 cells (Wong et al. 1995). Alternatively, activated cdk2 may directly phosphorylate pocket proteins associated with E2F-DP heterodimers and release free E2F-DP heterodimers.

Hyperphosphorylation of $R b$ family proteins appears to be important for $\mathrm{v}$-Abl-dependent induction of $\mathrm{c}$-myc transcription

The penultimate step in v-Abl-dependent induction of $c-m y c$ via the E2F site is a functional change in proteins that bind the E2F site. Upon association with $\mathrm{Rb}$ family "pocket proteins" the ability of E2F-DP heterodimers to activate transcription is ablated or changed to repression. Hyperphosphorylation releases pocket proteins and changes the activity of E2F-DP heterodimers (Chellapan 1994; Cobrinik 1996; Slansky and Farnham 1996). Our demonstration (Fig. 4A) that v-Abl signaling leads to hyperphosphorylation of $\mathrm{pRb}, \mathrm{p} 107$, and $\mathrm{p} 130$ is consistent with the idea that release of $\mathrm{Rb}$ family proteins from E2F-DP heterodimers is a critical step for induction of c-myc via the E2F site (Fig. 5). However, we cannot distinguish whether the actual mechanism of this induction is activation (by E2F-DP heterodimers), relief of repression (removal of E2F-DP-Rb complexes), or both.

$\mathrm{pRb}, \mathrm{p} 107$, and p130 each bind to particular members of the E2F family at distinct stages of the cell cycle and act in concert to limit the activation of E2F and the expression of E2F-responsive genes (Vairo et al. 1995; Weinberg 1995; Shiyanov et al. 1996). Our data do not distinguish specific roles for individual pocket proteins in the v-Abl-dependent induction of c-myc transcription. Although $\mathrm{pRb}$ repressed $\mathrm{c}-m y c$ promoter activity in the cotransfection assay (Fig. 4B), this does not establish a key role for $\mathrm{pRb}$ in vivo, as overexpression of any pocket protein would be expected to alter the balance between active and inactivate E2F-binding proteins.

\section{Autoregulatory loops}

c-Myc/Max was recently shown to activate transcription of cdc25A at a time in $G_{1}$ when c-Myc induction peaks (Galaktionov et al. 1996). This is consistent with previous work showing that c-Myc stimulates the activity of cyclin E- and D1-dependent kinases, possibly via cdc25, and leads to hyperphosphorylation of $\mathrm{pRb}$ (Steiner et al. 1995). c-Myc has also been reported to activate transcrip- tion of cyclin A and D1, and there are binding sites for c-Myc/Max in the E2F-1 promoter (Jansen-Durr et al. 1993; Johnson et al. 1994). If v-Abl activated E2F proteins by another Ras/Raf-dependent path, elevated c-Myc could induce transcription of cdc25, cyclin D1, cyclin A, and/or E2F-1. In this model c-Myc induction would cause and not result from increased cdk activity, hyperphosphorylation of pocket proteins, and altered E2Fbinding proteins. However, this model is not consistent with our observation that $\mathrm{p} 21$ blocks the ability of $\mathrm{v}-\mathrm{Abl}$ to trans-activate $\mathrm{c}-\mathrm{myc}$, which establishes a requirement for cdk activity in the path from v-Abl to c-myc. We favor the view that $\mathrm{v}$-Abl leads to a dynamic situation with autoregulatory loops in which c-Myc, cdc25, cdks, and E2F-1 can be both regulators and subject to regulation.

Our data provide the most complete understanding to date of a signaling pathway initiated by $\mathrm{v}-\mathrm{Abl}$ and raise important questions for further investigation. For example, a role for $\operatorname{cdc} 25 \mathrm{~A}$ and the prediction that other E2F-dependent genes may be activated by v-Abl or that other cdc25- or p21-regulated proteins may be sensitve to $\mathrm{v}$-Abl signaling can be tested. Experiments can be designed to ask whether signaling by $\mathrm{v}$-Abl mimics a normal proliferative signal or whether there are qualitative or quantitative differences in activation of specific proteins in the path. Finally, we can ask how v-Abl signaling may be related to signaling by $\mathrm{BCR} / \mathrm{ABL}$ or $\mathrm{c}-\mathrm{Abl}$.

\section{Materials and methods}

\section{Cells and transfections}

Monolayer culture of 4A2 (P-3T3) and D5 fibroblasts were grown in Iscove's modified Dulbecco's medium containing $10 \%$ newborn calf serum. DNA transfection was performed by the calcium phosphate precipitation method described by Chen and Ohayama $(1988)$. Cells $\left(5 \times 10^{5}\right)$ were seeded 1 day prior to transfection and fed with fresh medium $3 \mathrm{hr}$ before transfection. The cells were usually transfected with $5 \mu \mathrm{g}$ of reporter plasmid and $5 \mu \mathrm{g}$ of each expression plasmid unless indicated otherwise, and the total amount of transfected DNA was balanced by pUC19 plasmid. After an overnight incubation, the cells were washed, transferred to medium containing $0.5 \%$ serum, and harvested $96 \mathrm{hr}$ later, or transferred to medium containing $0.2 \%$ serum and harvested $24 \mathrm{hr}$ later. Luciferase activity for each transfection was measured as described previously (Riggs et al. 1993).

\section{Plasmids}

The c-myc promoter reporters $-1100 /+580 \mathrm{Luc},-140 /+340 \mathrm{Luc}$, and $+70 /+160$ Luc have been described previously (Wong et al. 1995). The plasmid expressing v-Abl, pAB160-19, and pLTR promoter control plasmid have also been described previously (Wong et al. 1995). Plasmid Ras N17, expressing the dominantnegative Ras, was kindly provided by A. M. Pendergast and has been described previously (Pendergast et al. 1993). Plasmid Ras V12, expressing the constitutive active Ras, was kindly provided by A. Gutierrez-Hartmann and has been described previously (Conrad and Gutierrez-Hartmann 1992). The plasmids expressing dominant-negative and constitutive active mutants of Raf, RafC4, and RafBXB were kindly provided by U.R. Rapp and have been described previously (Bruder et al. 1992). Plasmid 
V12N17rac1, expressing dominant-negative Rac, was a gift from A. Hall and has been described previously (Ridley et al. 1992). Plasmid CMVp21 was kindly provided by S.J. Elledge and described previously (Harper et al. 1993). Plasmid p65 was kindly provided by D. Baltimore (Massachusetts Institute of Technology, Cambridge). Plasmid pSV-Rb, an expression construct of $\mathrm{Rb}$, was kindly provided by S.P. Goff (Columbia University). Plasmid SRE-Fluc was kindly provided by R. Prywes and described previously (Johansen and Prywes 1994).

\section{Immunoprecipitation and kinase assays}

For immunoprecipitation, cells were washed twice with icecold PBS, harvested in lysis buffer containing $50 \mathrm{mM}$ HEPES $/ \mathrm{pH}$ 7.5 |, $10 \%$ glycerol, $150 \mathrm{~mm} \mathrm{NaCl}, 1 \mathrm{~mm}$ EDTA, $2.5 \mathrm{~mm}$ EGTA, $1 \mathrm{~mm}$ DTT, and $0.1 \%$ Tween 20 , supplemented with the phosphatase and protease inhibitors $1.0 \mathrm{mM} \mathrm{NaF}, 0.1 \mathrm{~mm}$ sodium orthovanadate, $5 \mu \mathrm{g}$ of leupeptin per $\mathrm{ml}, 10 \mu \mathrm{g}$ of aprotinin per $\mathrm{ml}, 5 \mu \mathrm{g}$ of pepstatin A per $\mathrm{ml}$, and $1.0 \mathrm{mM}$ PMSF and lysed by repeated passage through a 25 -gauge needle. Cellular debris was removed from soluble extracts by centrifugation at $16,000 \mathrm{~g}$ for $10 \mathrm{~min}$ at $4^{\circ} \mathrm{C}$. Lysates were precleared by incubation with protein $\mathrm{A} / \mathrm{G}$ )-agarose (Santa Cruz Biotechnology) for $30 \mathrm{~min}$ at $4^{\circ} \mathrm{C}$. Endogenous cdk2-containing complexes were immunoprecipitated for $2 \mathrm{hr}$ at $4^{\circ} \mathrm{C}$ using $1 \mu \mathrm{g}$ cdk 2 antibody and then incubated with $20 \mu \mathrm{l}$ of protein A-agarose beads (50\% vol/vol) for 2 hr at $4^{\circ} \mathrm{C}$. Immunoprecipitates were washed four times with lysis buffer and twice with the kinase reaction buffer $(50 \mathrm{mM}$ HEPES at $\mathrm{pH} 7.5,10 \mathrm{mM} \mathrm{MgCl}_{2}, 1 \mathrm{~mm}$ DTT, $2.5 \mathrm{~mm}$ EGTA). The kinase activity associated with anti-cdk2 immunocomplexes was assayed in $30 \mu \mathrm{l}$ of kinase reaction buffer containing $5 \mu \mathrm{g}$ of histone $\mathrm{HI}$ (Boehringer Mannheim), $5 \mu \mathrm{Ci}$ of $\left[\gamma^{-32} \mathrm{P}\right] \mathrm{ATP}$. Reactions were carried out for $15 \mathrm{~min}$ at $30^{\circ} \mathrm{C}$ and stopped by the addition of Laemmli sample buffer, and the reaction products were electrophoresed in a 10\% SDS-polyacrylamide gel, whereupon the gels were dried, visualized by autoradiography, and quantitated with a PhosphorImager (Molecular Dynamics). Endogenous cdk4-containing complexes were immunoprecipitated using $20 \mu \mathrm{l}$ of protein G-agarose precoated with $2 \mu \mathrm{g}$ of cyclin D1 antibody. The kinase assay was performed by using 1 $\mu \mathrm{g}$ of GST-Rb (769-921) fusion proteins (Santa Cruz Biotechnology) as the substrates. Reactions were carried out for $30 \mathrm{~min}$ at $30^{\circ} \mathrm{C}$, the products were electrophoresed in a $10 \%$ SDS-polyacrylamide gel; and visualize and quantitated as above. v-Abl was immunoprecipitated using $5 \mu \mathrm{l}$ of antiserum according to standard procedure.

\section{Western blot (immunoblot) analysis}

The D5 whole-cell extracts were made the same way as the lysates for immunoprecipitation (see above). Equal amounts of cellular proteins were separated by SDS-PAGE and transferred to nitrocellulose membranes. The membranes were blotted with $5 \%$ nonfat milk in Tris buffer at $\mathrm{pH} 7.5(50 \mathrm{~mm}$ Tris- $\mathrm{HCl}$, $125 \mathrm{~mm} \mathrm{NaCl}, 0.2 \%$ Tween 20 ) for $1 \mathrm{hr}$ at room temperature and then immunoblotted with the indicated primary antibodies in $2 \%$ nonfat milk in the same Tris buffer for $2 \mathrm{hr}$ at room temperature or overnight at $4^{\circ} \mathrm{C}$. Antibodies immunoblotted to the membrane were detected by using horseradish peroxidaselinked secondary antibodies and an enhanced chemiluminescence detection system from Pierce (Rockford, IL).

\section{Antibodies}

To characterize proteins by immunoblot and to immunoprecipitate cdk complexes the following antibodies were used: The
$\mathrm{pRb}$ monoclonal antibody $(\mathrm{Q} 3-245)$ was obtained from PharMingen (San Diego, CA). The p107 (SD9), p130 (C-20), cdk2 (M2), and cdk4 (C-22) polyclonal antibodies and phosphotyrosine monoclonal antibody (PY20) were from Santa Cruz Biotechnology (Santa Cruz, CA). The cyclin DI monoclonal antibody (DCS-11) was from NeoMarkers (Fremont, CA). Murine c-Myc antiserum was described previously (Shrivastava et al. 1996). Antiserum against v-Abl was a gift from Dr. S. Goff.

\section{Acknowledgments}

We are grateful to Drs. S. Goff, N. Rosenberg, O. Witte, D. Cobrinik, S. Chellapan, and members of our laboratories for helpful discussions and to Drs. S. Goff, S. Chellapan, D. Cobrinick, and A. Henderson for critically reading the manuscript. We appreciate receiving cell lines and plasmids from Drs. J. Wang, A.M. Pendergast, A. Gutierrez-Hartmann, U.R. Rapp, D. Baltimore, A. Hall, S.J. Elledge, and R. Prywes. This work was supported by grants from the American Cancer Society (VM130) and the U.S. Army Medical Research and Material Command to K.C.

The publication costs of this article were defrayed in part by payment of page charges. This article must therefore be hereby marked "advertisement" in accordance with 18 USC section 1734 solely to indicate this fact.

\section{References}

Adams, P.D. and W.G. Kaelin, Jr. 1995. Transcriptional control by E2F. Semin. Cancer Biol. 6: 99-108.

Afar, D.E., A. Goga, J. McLaughlin, O.N. Witte, and C.L. Sawyers. 1994. Differential complementation of Bcr-Abl point mutants with c-Myc. Science 264: 424-426.

Bruder, J.T., G. Heidecker, and U.R. Rapp. 1992. Serum-, TPA-, and Ras-induced expression from Ap-1/Ets-driven promoters requires Raf-1 kinase. Genes \& Dev. 6: 545-556.

Chellapan, S. 1994. The E2F transcription factor: Role in cell cycle regulation and differentiation. Mol. Cell. Differ. 2: 201-220.

Chen, C.A. and H. Ohayama. 1988. Calcium phosphate-mediated gene transfer: A highly efficient transfection system for stably transforming cells with plasmid DNA. BioTechniques 6: 632-638.

Chen, P.L., D.J. Riley, and W.H. Lee. 1995. The retinoblastoma protein as a fundamental mediator of growth and differentiation signals. Crit. Rev. Eukaryotic Gene Expression 5: 7995.

Chen, Y.-Y. and N. Rosenberg. 1992. Lymphoid cells transfromed by Abelson virus require the $\mathrm{v}$-abl protein-tyrosine kinase only during early G1. Proc. Nat1. Acad. Sci. 89: 66836687.

Cleveland, J., M. Dean, N. Rosenberg, J. Wang, and U. Rapp. 1989. Tyrosine kinase oncogenes abrogate interleukin-3 dependence of murine myeloid cells through signaling pathways involving c-myc: Conditional regulation of c-myc transcription by temperature-sensitive v-abl. Mol. Cell. Biol. 9: 5685-5695.

Cobrinik, D. 1996. Regulatory interactions among E2Fs and cell cycle control proteins. Curr. Top. Microbiol. Immunol. 208: 31-61.

Conrad, K.E. and A. Gutierrez-Hartmann. 1992. The ras and protein kinase A pathways are mutually antagonistic in regulating rat prolactin promoter activity. Oncogene 7: 1279-1286.

Dudley, D.T., L. Pang, S.J. Decker, A.J. Bridges, and A.R. Saltiel. 
1995. A synthetic inhibitor of the mitogen-activated protein kinase cascade. Proc. Natl. Acad. Sci. 92: 7686-7689.

Duyao, M.P., A.J. Buckler, and G.E. Sonenshein. 1990a. Interaction of an NF-kB-like factor with a site upstream of the c-myc promoter. Proc. Nat1. Acad. Sci. 87: 4727-4731.

Duyao, M.P., D.J. Kessler, D.B. Spicer, and G.E. Sonenshein. $1990 \mathrm{~b}$. Binding of NF-KB-like factors to regulatory sequences of the c-myc gene. Curr. Top. Microbiol. Immunol. 166: $211-220$.

Feller, S.M., B. Knudsen, and H. Hanafusa. 1994. c-Abl kinase regulates the protein binding activity of c-Crk. EMBO $\mathrm{J}$. 13: $2341-2351$.

Galaktionov, K., A.K. Lee, J. Eckstein, G. Draetta, J. Meckler, M. Loda, and D. Beach. 1995. CDC25 phosphatases as potential human oncogenes. Science 269: 1575-1577.

Galaktionov, K., X. Chen, and D. Beach. 1996. Cdc25 cell-cycle phosphatase as a target of c-myc. Nature 382: 511-517.

Goga, A., J. McLaughlin, D.E. Afar, D.C. Saffran, and O.N. Witte. 1995. Alternative signals to RAS for hematopoietic transformation by the BCR-ABL oncogene. Cell 82: 981-988.

Harper, J.W., G.R. Adami, N. Wei, K. Keyomarsi, and S.J. Elledge. 1993. The p21 Cdk-interacting protein Cip1 is a potent inhibitor of G1 cyclin-dependent kinases. Cell 75: $805-816$.

Jansen-Durr, P., A. Meichle, P. Steiner, M. Pagano, K. Finke, J. Botz, J. Wessbecher, G. Draetta, and M. Eilers. 1993. Differential modulation of cyclin gene expression by MYC. Proc. Nat1. Acad. Sci. 90: 3685-3689.

Jinno, S., K. Suto, A. Nagata, M. Igarashi, Y. Kanaoka, H. Nojima, and H. Okayama. 1994. Cdc25A is a novel phosphatase functioning early in the cell cycle. $E M B O J$. 13: 1549-1556.

Johansen, F.E. and R. Prywes. 1994. Two pathways for serum regulation of the $\mathrm{c}$-fos serum response element require specific sequence elements and a minimal domain of serum response factor. Mol. Cell. Biol. 14: 5920-5928.

Johnson, D.G., K. Ohtani, and J.R. Nevins. 1994. Autoregulatory control of E2F1 expression in response to positive and negative regulators of cell cycle progression. Genes \& Dev. 8: 1514-1525.

Marshall, M.S. 1995. Ras target proteins in eukaryotic cells. FASEB J. 9 : 1311-1318.

Matsushime, H., D.E. Quelle, S.A. Shurtleff, M. Shibuya, C.J Sherr, and J.Y. Kato. 1994. D-type cyclin-dependent kinase activity in mammalian cells. Mol. Cell. Biol. 14: 2066-2076.

Nichols, G.L., M.A. Raines, J.C. Vera, L. Lacomis, P. Tempst, and D.W. Golde. 1994. Identification of CRKL as the constitutively phosphorylated $39-\mathrm{kD}$ tyrosine phosphoprotein in chronic myelogenous leukemia cells. Blood 84: 2912-2918.

Owen-Lynch, P.J., A.K. Wong, and A.D. Whetton. 1995. v-Ablmediated apoptotic suppression is associated with SHC phosphorylation without concomitant mitogen-activated protein kinase activation. J. Biol. Chem. 270: 5956-5962.

Pendergast, A., L. Quilliam, L. Cripe, C. Bassing, Z. Dai, N. Li, A. Batzer, K. Rabun, C. Der, J. Schlessinger, and M. Gishizky. 1993. BCR-ABL-induced oncogenesis is mediated by direct interaction with the $\mathrm{SH} 2$ domain of the GRB-2 adaptor protein. Cell 75: 175-185.

Raffel, G., K. Parmar, and N. Rosenberg. 1996. In vivo association of v-Abl with Shc mediated by a non-phosphotyrosinedependent SH2 interaction. J. Biol. Chem. 271: 4640-4645.

Ren, R., Z.S. Ye, and D. Baltimore. 1994. Abl protein-tyrosine kinase selects the Crk adapter as a substrate using SH3-binding sites. Genes \& Dev. 8: 783-795.

Renshaw, M., E. Kiipreos, M. Albrecht, and J. Wang. 1992. Oncogenic v-Abl tyrosine kinase can inhibit or stimulate growth, depending on the cell context. EMBO T. 11: 3941-3951.
Renshaw, M.W., E. Lea-Chou, and J.Y.J. Wang. 1996. Rac is required for $\mathrm{v}-\mathrm{Abl}$ tyrosine kinase to activate mitogenesis. Curr. Biol. 6: 76-83.

Ridley, A.J., H.F. Paterson, C.L. Johnston, D. Diekmann, and A. Hall. 1992. The small GTP-binding protein rac regulates growth factor-induced membrane ruffling. Cell 70: 401-410.

Riggs, K.R., S. Saleque, K. Wong, K.T. Merrell, J.-S. Lee, Y. Shi, and K. Calame. 1993. Yin yang-1 activates the c-Myc promoter. Mol. Cell. Biol. 13: 7487-7495.

Risser, R. and P.L. Green. 1988. Abelson virus: Current status of a viral oncogene. Proc. Soc. Exp. Biol. Med. 188: 235-242.

Sawyers, C., W. Callahan, and O.N. Witte. 1992. Dominant negative MYC blocks transformation by ABL oncogenes. Cell 70: 901-910.

Sawyers, C.L., J. McLaughlin, and O.N. Witte. 1995. Genetic requirement for Ras in the transformation of fibroblasts and hematopoietic cells by the Bcr-Abl oncogene. I. Exp. Med. 181: 307-313.

Shiyanov, P., S. Bagchi, G. Adami, J. Kokontis, N. Hay, M. Arroyo, A. Morozov, and P. Raychaudhuri. 1996. p21 disrupts the interaction between cdk2 and the E2F-p130 complex. Mol. Cell. Biol. 16: 737-744.

Shrivastava, A., J. Yu, S. Artandi, and K. Calame. 1996. YY1 and c-Myc associate in vivo in a manner that depends on c-Myc levels. Proc. Natl. Acad. Sci. 93: 10638-10641.

Slansky, J.E. and P.J. Farnham. 1996. Introduction to the E2F family: Protein structure and gene regulation. Curr. Top. Microbiol. Immunol. 208: 1-30.

Smith, M.R., S.J. DeGudicibus, and D.W. Stacey. 1986. Requirement for c-ras proteins during viral oncogene transformation. Nature 320: 540 -543.

Stacey, D., M. Roudebush, R. Day, S. Moser, J. Gibbs, and L. Feig. 1991. Dominant inhibitory Ras mutations demonstrate the requirement for Ras activity in the action of tyrosine kinase oncogenes. Oncogene 6: 2297-2304.

Steiner, P., A. Philipp, J. Lukas, D. Godden-Kent, M. Pagano, S. Mittnacht, J. Bartek, and M. Eilers. 1995. Identification of a Myc-dependent step during the formation of active G1 cyclin-cdk complexes. EMBO T. 14: 4814-4826.

Terada, Y., M. Tatsuka, S. Jinno, and H. Okayama. 1995. Requirement for tyrosine phosphorylation of Cdk4 in Gl arrest induced by ultraviolet irradiation. Nature 376: 358-362.

Vairo, G., D.M. Livingston, and D. Ginsberg. 1995. Functional interaction between E2F-4 and p130: Evidence for distinct mechanisms underlying growth suppression by different retinoblastoma protein family members. Genes \& Dev. 9: 869 881.

Weinberg, R.A. 1995. The retinoblastoma protein and cell cycle control. Cell 81: 323-330.

Wong, K.K., X. Zou, K.T. Merrell, A.J. Patel, K.B. Marcu, S. Chellappan, and K. Calame. 1995. v-Abl activates c-myc transcription through the E2F site. Mol. Cell. Biol. 15: 65356544.

Xiong, Y., G.J. Hannon, H. Zhang, D. Casso, R. Kobayashi, and D. Beach. 1993.p21 is a universal inhibitor of cyclin kinases (see comments). Nature 366: 701-704

Zhu, L., E. Harlow, and B.D. Dynlacht. 1995. p107 uses a p21CIP1-related domain to bind cyclin/cdk2 and regulate interactions with E2F. Genes \& Dev. 9: 1740-1752. 


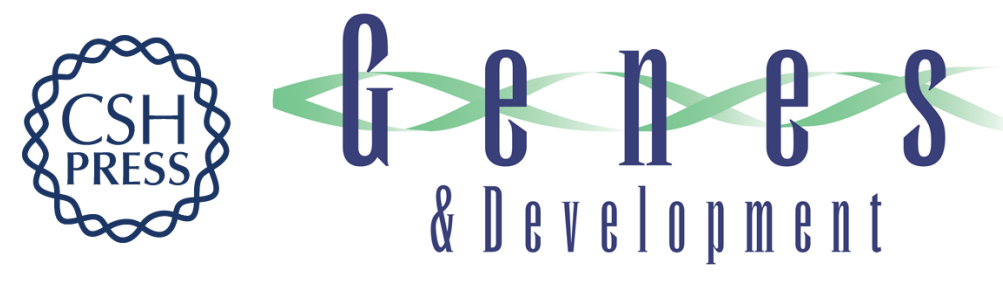

\section{Induction of C-myc transcription by the v-Abl tyrosine kinase requires Ras, Raf1, and cyclin-dependent kinases.}

X Zou, S Rudchenko, K Wong, et al.

Genes Dev. 1997, 11:

Access the most recent version at doi:10.1101/gad.11.5.654

References This article cites 48 articles, 22 of which can be accessed free at: http://genesdev.cshlp.org/content/11/5/654.full.htmI\#ref-list-1

License

Email Alerting

Receive free email alerts when new articles cite this article - sign up in the box at the top Service right corner of the article or click here.

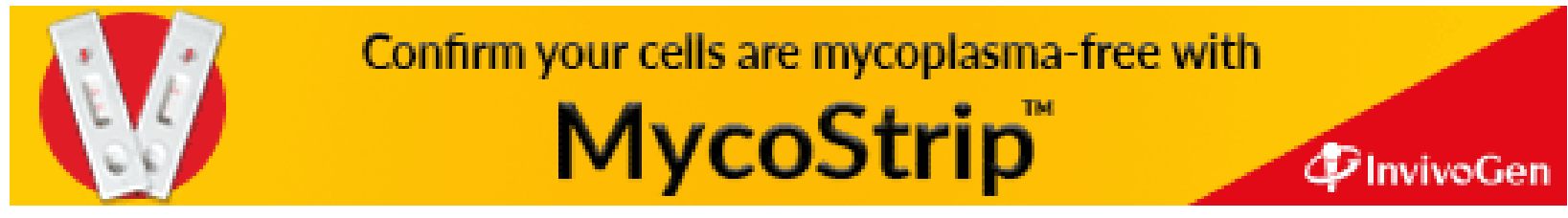

